\title{
INITIAL ANALYSIS OF HELICOPTER IMPACT ON HOSPITAL HELIPADS
}

\author{
Wiesław Krzymień, Sławomir Cieślak \\ Institute of Aviation \\ Warsaw \\ wieslaw.krzymien@ilot.edu.pl, slawomir.cieslak@ilot.edu.pl
}

\begin{abstract}
The need to quickly provide assistance to victims of accidents or seriously ill has created the need for the construction of helipads at selected hospitals. Their operation and the conditions of use are governed by regulation of the Ministry of Health on Hospital Emergency Ward (SOR) and rules required by the Civil Aviation Authority.

The direct vicinity of the helipads causes impact of landing and departing helicopters on buildings, people and hospital equipment as well as the construction of the airfield. This article presents vibroacoustic impact of helicopters on helipads' measurement methods and the results of the preliminary measurements to estimate the impact of Helicopter Air Rescue (LPR) on adjacent buildings and surroundings.
\end{abstract}

Keywords: Helipads, helicopter noise, ground tests.

\section{INTRODUCTION}

The need for the provision of rapid and professional medical assistance as well as modern technical capabilities have resulted in creating air transportation system of accident victims or seriously ill persons. This system is formed by trained pilots, mechanics and medics, along with hardware (new helicopters and their equipment) and specialized medical care units (hospitals). General conditions for the operation of Polish Air Transport for medical needs is governed by the Act of 8.09.2006 about the State Emergency Medical Services (Dz.U.191 item 1410) and Regulation of the Ministry of Health of 3.11.2011 r. on hospital emergency ward (Dz.U. 237 item 1420) [2]. The law provides the requirements a short transport time which determines the location of the helipads or airfield as close as possible to the hospital. An additional requirement is to ensure the safe functioning of possible landing for $24 \mathrm{~h}$ in the provisions of the airport weather conditions. 
These requirements indicate two basic solutions for landing fields near hospitals:

1. Landing field - set usually outside the city or in its outskirts.

The advantages are: a small investment for the construction and low maintenance costs.

The disadvantages are: a large area covered by the take-off and landing requirements, height and distance from other objects (buildings, trees, poles, etc.), and a longer route between the helicopter and the hospital emergency wards (SOR).

2. Elevated helipads - most often used in urban areas (near the city center).

The advantages are: a small area occupied by the airstrip and the shortest route between the helicopter and the SOR.

Disadvantages: the high cost of construction, special conditions for the landing, requirements of safe operation, the big costs of winter maintenance and dangerous effects of the accident helicopter during take-off or landing.

In Poland about 240 helipads are used near hospitals, 75 of which do not have equipment for night landings.

Among them work 31 elevated helipads (25 on the building and 6 free-standing) - all are 24/7.

Due to the requirements and the area of the operation of the LPR there is an expectation to increase the number of elevated helipads.

Most of them are built on hospital buildings. For example, Figure 1. shows an elevated helipad on South Hospital in Warsaw.

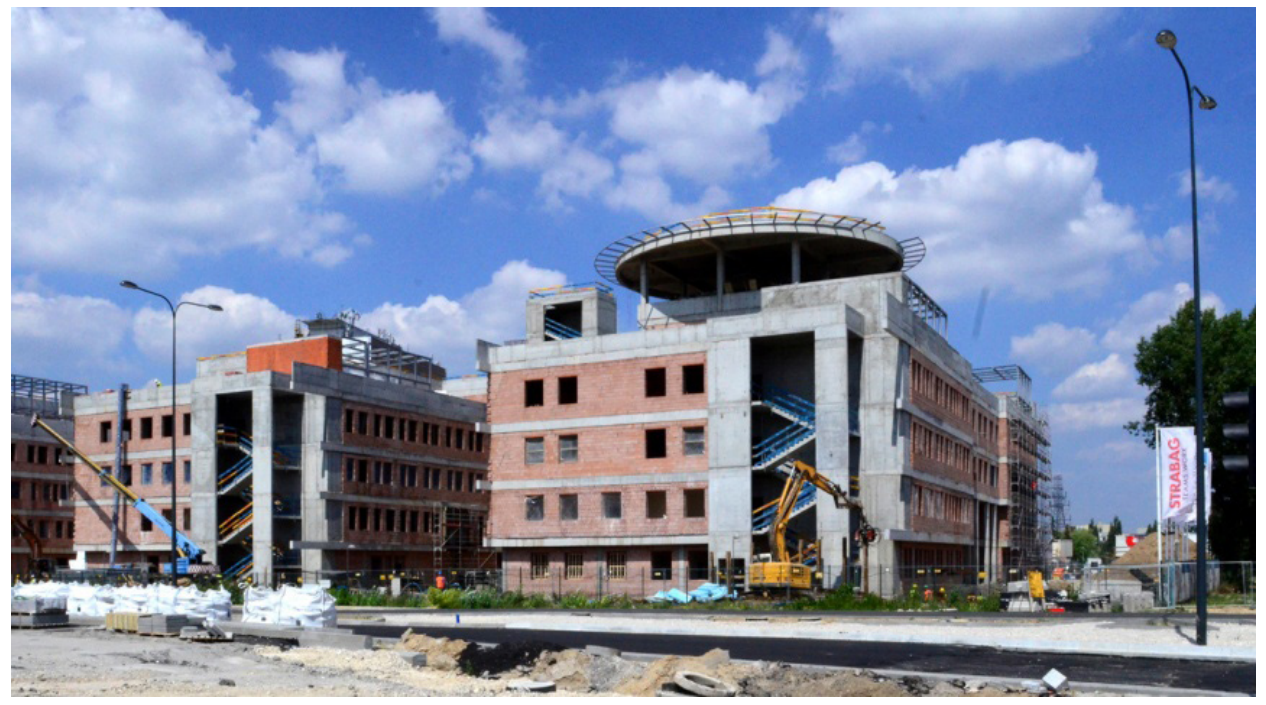

Fig. 1. Helipad on South Hospital in Warsaw under construction. [W. Krzymień, 2018].

Consequences of placing helipad on the building, and in very close proximity to other buildings which are exposed to a working helicopter, is also an important source of vibrations and noise. The impact of the helicopter on the surrounding environment during the boot, take-off, landing and turn off the drive is through:

- engine noise,

- noise of blade (the tips) of the main rotor, 
- noise of the tail rotor,

- blowing out the main rotor,

- pulsation of blow of blades,

- load from "hard landing",

- vibrations transmitted into the landing strip by the landing gear.

A team of researchers of the Institute of Aviation performed preliminary measurements, which were designed to estimate the type and size of the burdensome impact of the helicopter on the environment. These studies included:

- a general noise measurement and indication of its source,

- measurement of air pressure under rotor and its pulsation.

Some results of the measurements are presented in this article.

\section{SOURCES OF NOISE}

By courtesy of the staff of the Center of LPR (airport Warsaw-Babice) the initial measurement of noise emitted by helicopter EC-135-starting and landing on a disc landing was made - Fig. 2. Helicopters EC-135 are the basic equipment of the LPR and will be used in the next few years.

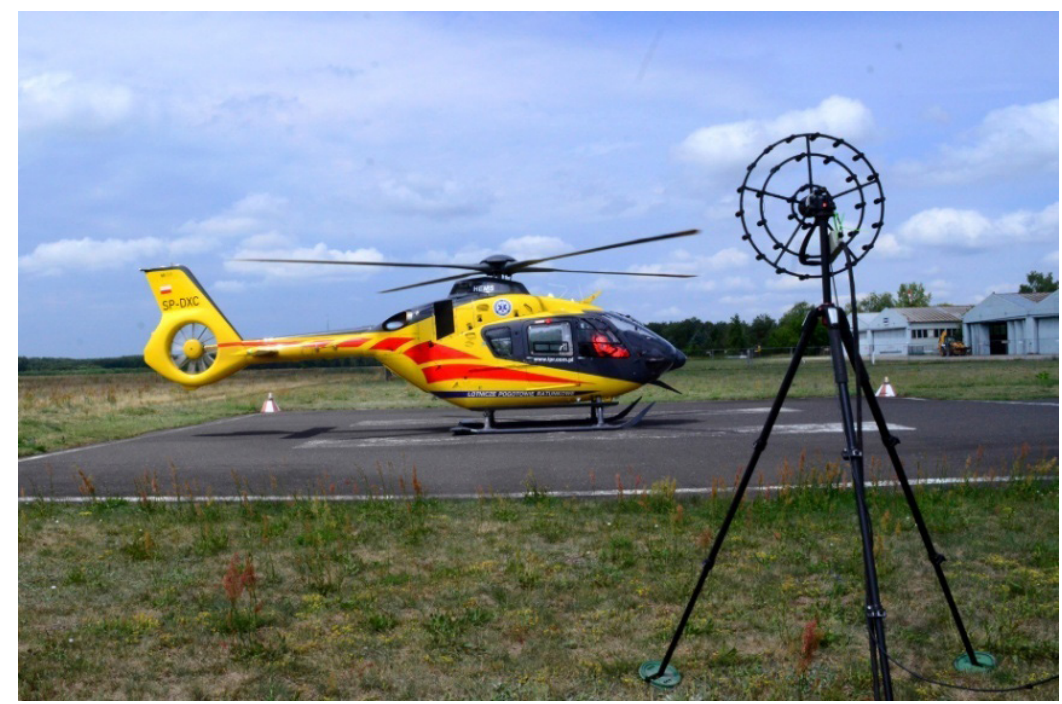

Fig. 2. Measurement with the acoustic camera to determine the sources and noise spectrum of the helicopter

[W. Krzymień, 2018].

A general measurement of noise with the microphone was made $15 \mathrm{~m}$ from the helicopter EC-135. The goal was an indication of the frequency of bands sounds, which can be a source of acoustic excitation of building elements as well as hassle for nearby people. The noise was measured sequentially on the left and right side of the helicopter and in front of it in the same operating conditions. Figure 3. shows the spectrum charts of measured noise pressure. 


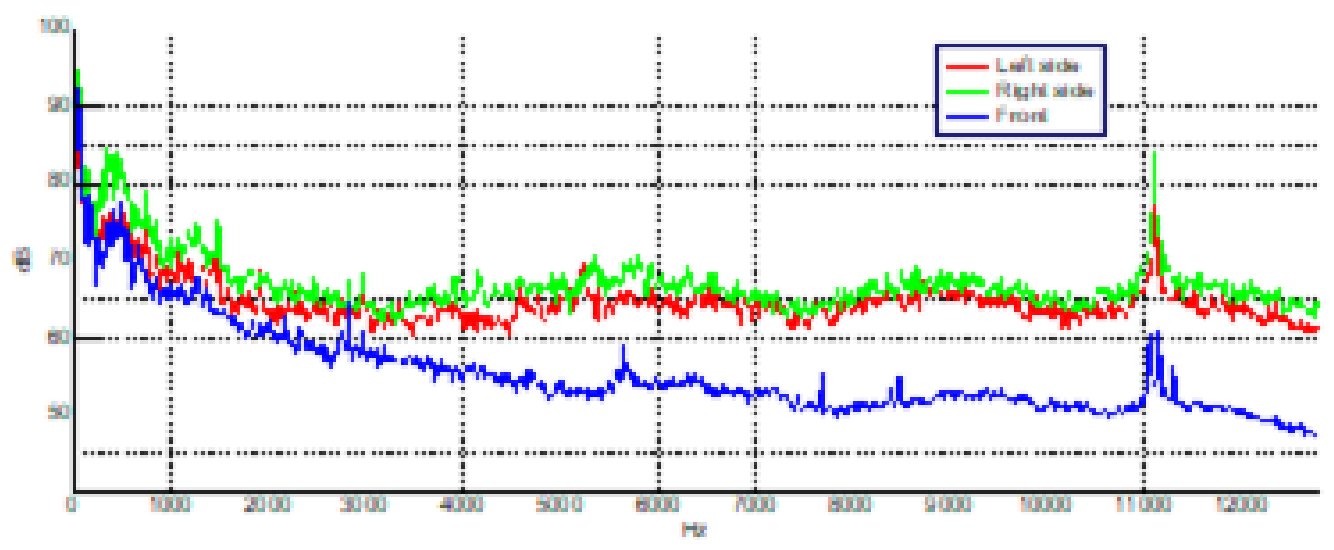

Fig. 3. Spectrum of the noise emitted by the helicopter EC-135 in front and from the left and right side of $\mathrm{dB}$ [S. Cieślak, 2018]

Figure 4 shows the sound pressure level in 1/3-octave type A corrected characteristics, which correspond to the noise heard by the human ear.
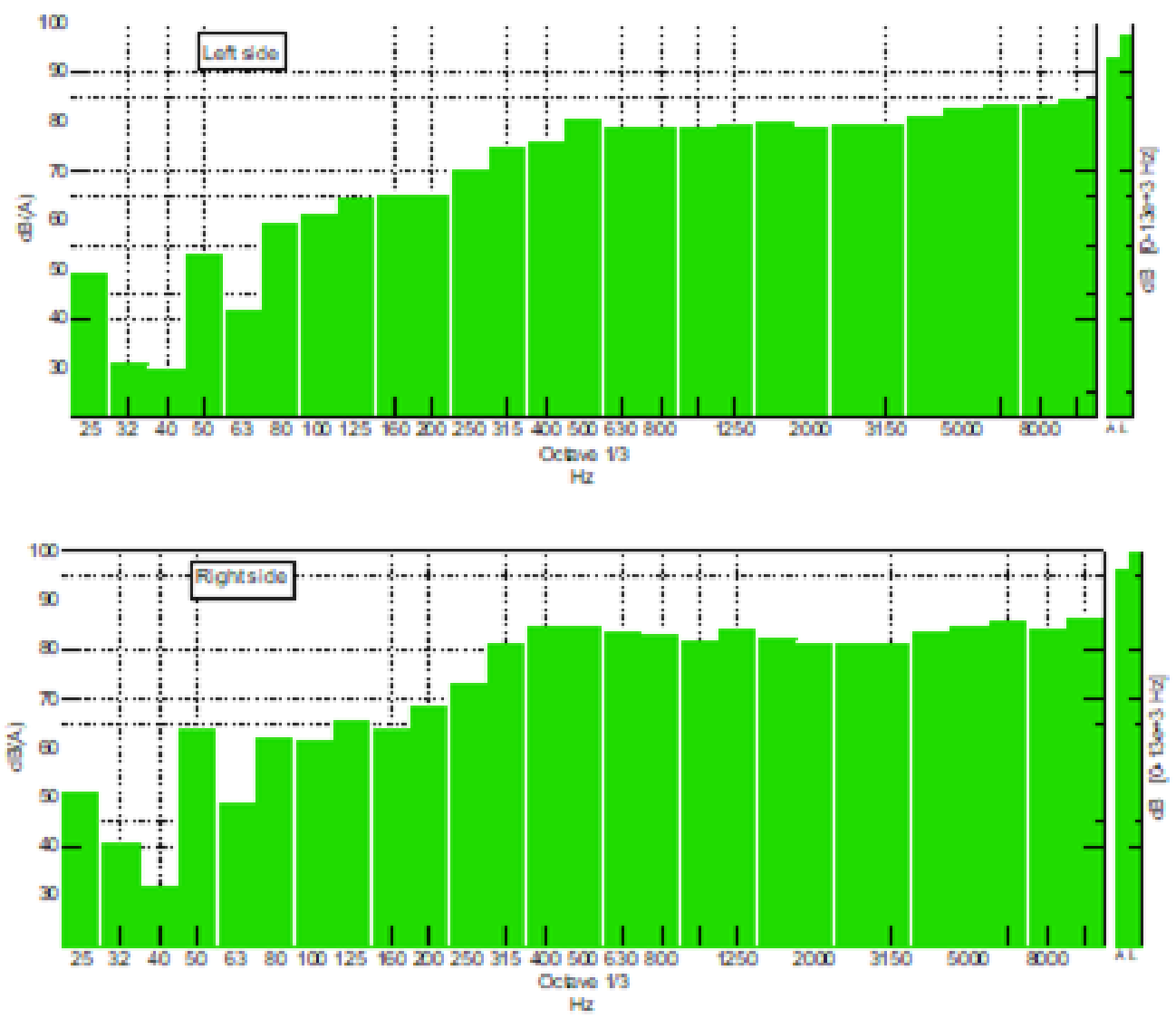


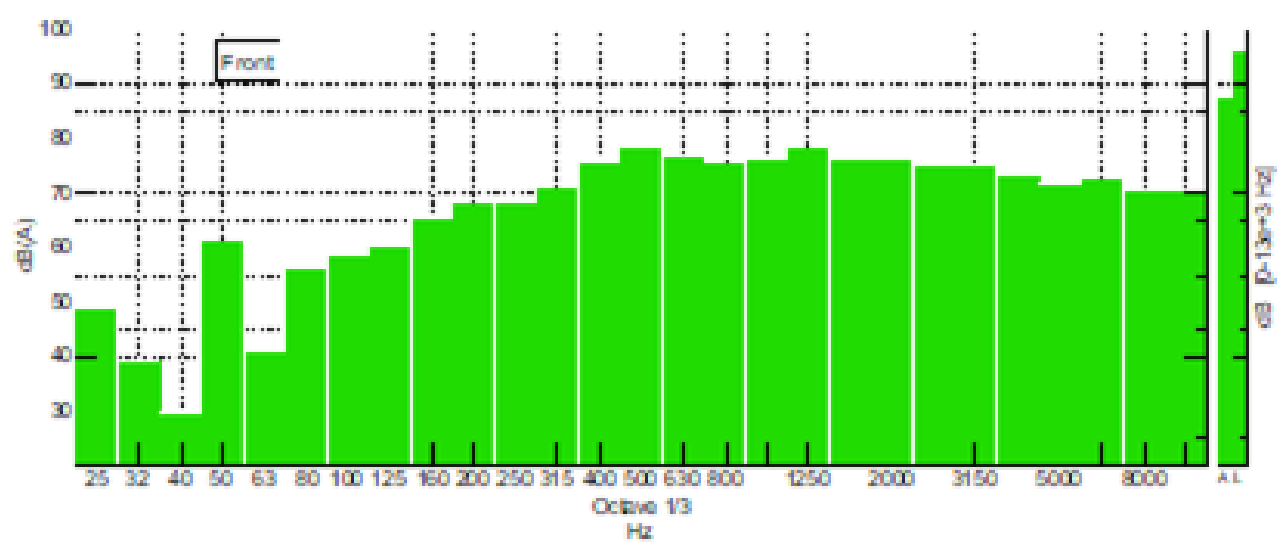

Fig. 4. Amplitude-frequency diagram in a 1/3 octave format of the measured noise [S. Cieślak, 2018]

The characteristics set out in Figure 3 shows that the helicopter is an important source of noise with a wide frequency spectrum. The low-frequency noise is dominant and the sound pressure level (in linear scale) in the range of around $2 \mathrm{kHz}$ decreases with frequency. In the frequency range from approximately $2 \mathrm{kHz}$ to $12 \mathrm{kHz}$ the noise level fluctuates around similar values. At the frequency of about $11 \mathrm{kHz}$ the graph shows a strong increase in the amplitude proving the existence of sources of high-frequency noise about mono-harmonic nature.

In noise charts appreciable by human ear (Figure 4), you can see that among the low-frequency dominated noise is located in $1 / 3$ octave band of the $25 \mathrm{~Hz}$ and $50 \mathrm{~Hz}$. Sound pressure level increases up to the frequency about $500 \mathrm{~Hz}$, while in the higher band $1 / 3$ octave levels are similar. For measurements on the side of the helicopter, a noticeable increase in noise level is also along with the frequency in $1 / 3$ octave bands above $3.15 \mathrm{kHz}$. This suggests that the high frequency noise source is located on the side of the helicopter.

The characteristics presented in Figures 3 and 4 show a similar noise levels measured from the left and from the right side of the helicopter, while the lower noise level was measured on the front. This is useful information for planning air operations on the helipad as well as when planning the deployment of the infrastructure elements.

Figure 5 shows the sound pressure charts in a narrower frequency range (up to $100 \mathrm{~Hz}$ ) in absolute units $[\mathrm{Pa}]$. It allows to explain the reason of the existence for low frequency noise which comes from rotating rotor blades. A visible growth of sound pressure with a frequency of about $27 \mathrm{~Hz}$ corresponds to the rotor frequency multiplied by the number of blades (4). Other "peaks" of acoustic pressure at higher frequencies correspond to the next harmonic frequencies. This noise is heard by the human ear but, significantly, it can also cause acoustic excitation for the equipment of a helipad.

Using the acoustic camera for the location of the sound source was identified. The measurements were made during boot and just before take-off of the helicopter. This method was used already in the Institute of Aviation to measure the noise sources of the gyrocopter [5] and the hovercraft [6]. Figure 6 shows the process of the measured sound pressure over time (chart marked number 1), the spectrum of noise (2), a loudness map of sound pressure in the coordinated time and frequency (3) an acoustic sound source map (4) calculated for a hypothetical plane tangential to the helicopter and $15 \mathrm{~m}$ away from the camera. In the background of the photograph of the helicopter is the source of noise which 
is the exhaust of turbine engine (and its reflection from a paved surface landing). This is the dominant noise in a wide range of frequencies with reinforced mono-harmonic sound of a frequency slightly above $11 \mathrm{kHz}$. The frequency of the sound increases with an increment in engine power before and during take-off.

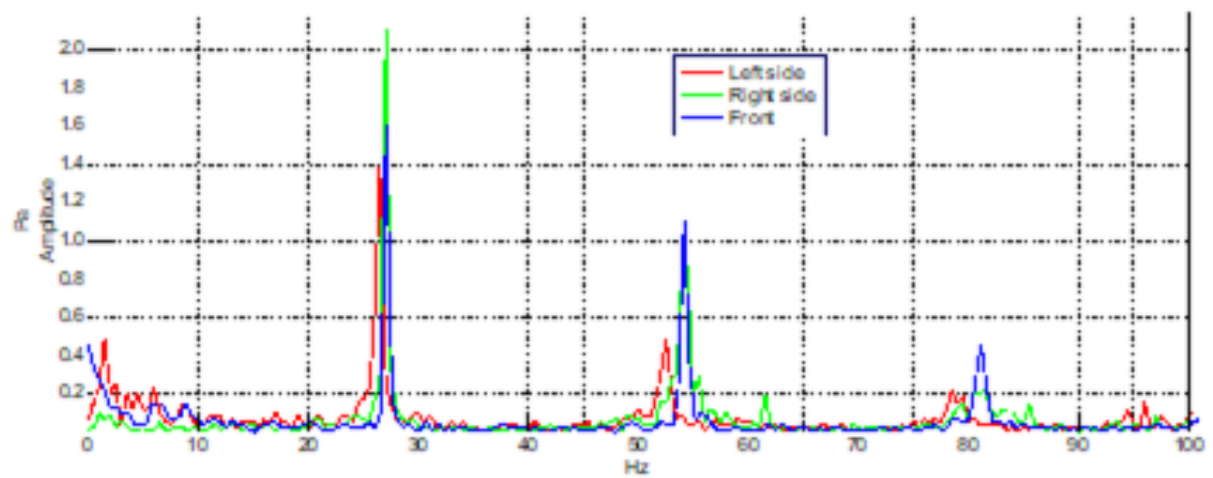

Fig. 5. Amplitude-frequency diagram of the measured noise in frequency range up to $100 \mathrm{~Hz}$ [S. Cieślak, 2018]

The acoustic map shown in Figure 6 is drawn up for the full test of the frequency band. Other sources of noise (rotor blades, propeller) emit mostly low-frequency sound up to about $500 \mathrm{~Hz}$, which prevents its precise location with the use of an acoustic camera. In the range of high frequencies there are no clear sources of sound higher than the noise of the engine exhaust.
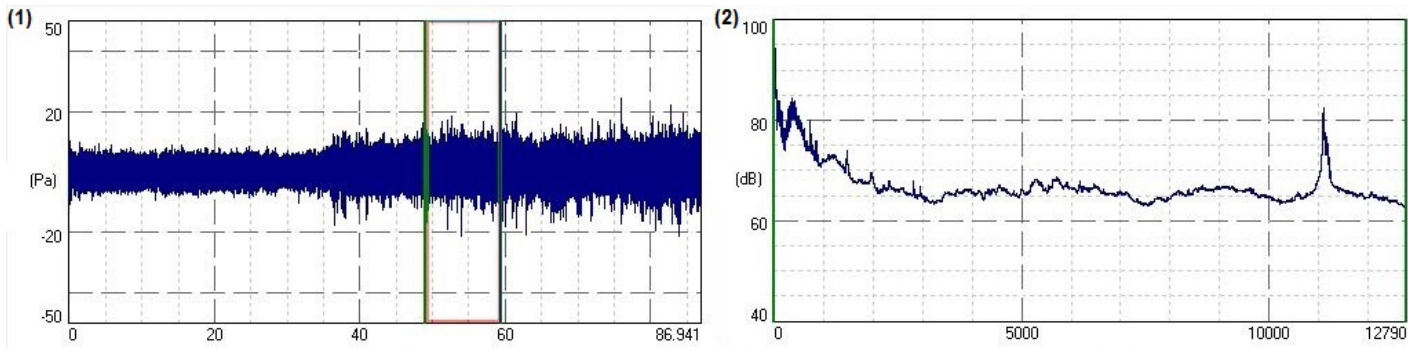

(3)

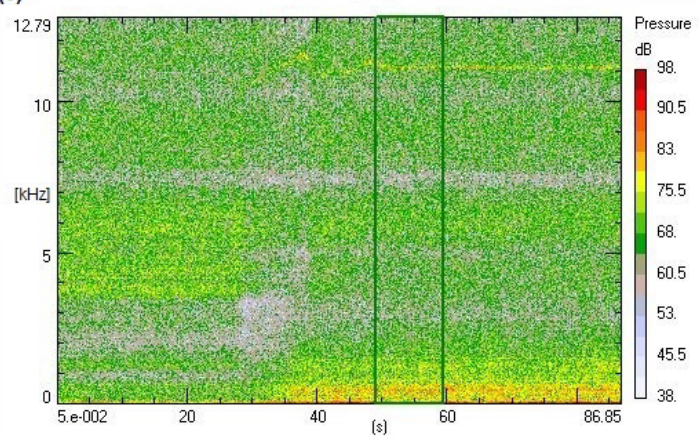

(4)

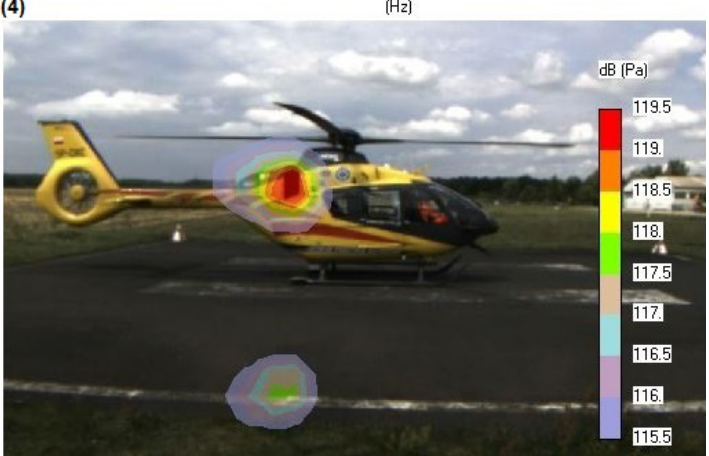

Fig. 6. Helicopter EC-135. The results of measurement of noise sources with the acoustic camera before take-off [S. Cieślak, 2018] 


\section{MEASUREMENT OF THE MAIN ROTOR INFLUENCE}

At boot time and brake of the helicopter main rotor blades may occur vibrations, which are transmitted to the ground. Variable speed rotor and wind can cause vibration resonance of the helicopter on the chassis. This kind of vibrations usually occur in the case of helicopters with three blades main rotor heads. Such analyses were made in IoA for various helicopters (e.g. [7]). In the case of helicopters EC-135 the manufacturer prepared a special procedure and instrumentation for monitoring and balancing the main rotor blades and balancing the tail fan, which provides minimization of their vibration in the entire frequency range of the rotary (and multiples of the number of blades). This excitation is small, however, low frequencies may affect the helipad construction or be transmitted by it.

Another type of impact on the immediate environment is a stream under the main rotor. Its size depends on the main rotor diameter and flow velocity under the rotor of the currently produced lift. This flow is pulsating with a frequency of a multiple of the number of blades and rotation of the rotor. In addition, the flow of main rotor stream is subjected to wind and obstacles in the immediate vicinity, which causes additional disorders. This is the cause of the vibration excitation structure landing and negative impressions.

The next issue is the noise caused by the flow of the tips of the rotating blades, which depends on keeping the speed and shape of the tips of blades.

The investigation of properties of the main rotor stream and the noise of the tips of the blade can be safety carried out only on a specially prepared stand where a helicopter or a special tower to test the rotors can be anchored. The stand with a tower also allows to reduce the impact of helicopter drive noise. On this stand the rotor noise measurements and pressure pulsations were conducted for the main rotor unmanned helicopter ILX-27 designed at the IoA [8]. The test stand with the tested main rotor is shown in Figure 7.

Fig. 8. shows the image of noise sources of two-blades main rotor of the unmanned helicopter ILX-27.

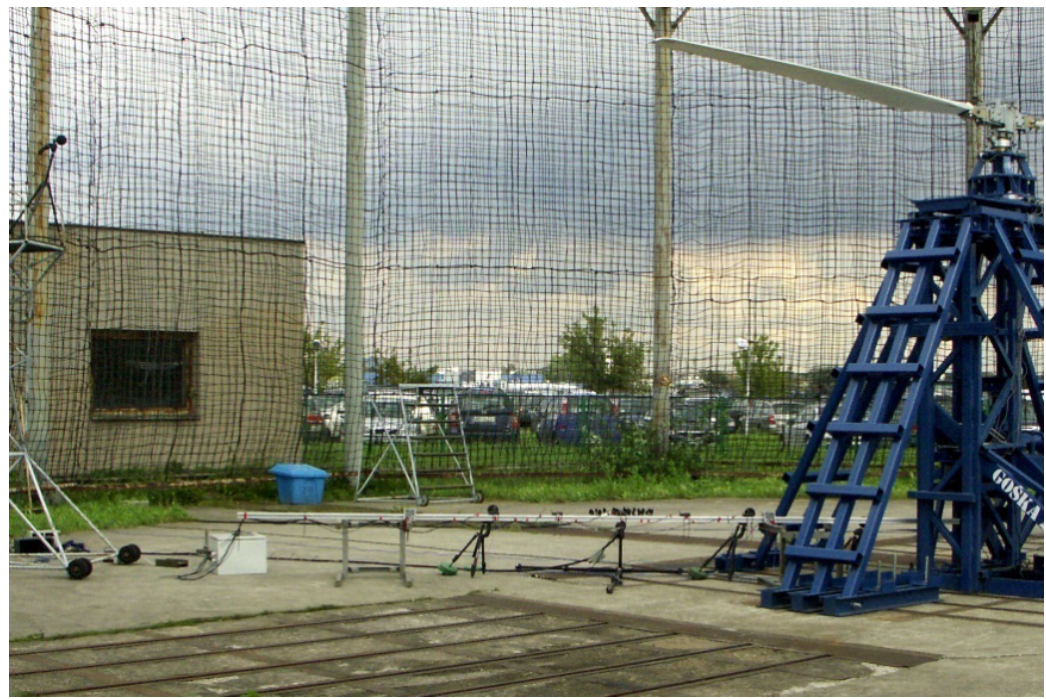

Fig. 7. The stand for investigation of helicopter main rotors [W. Krzymień, 2018]. 

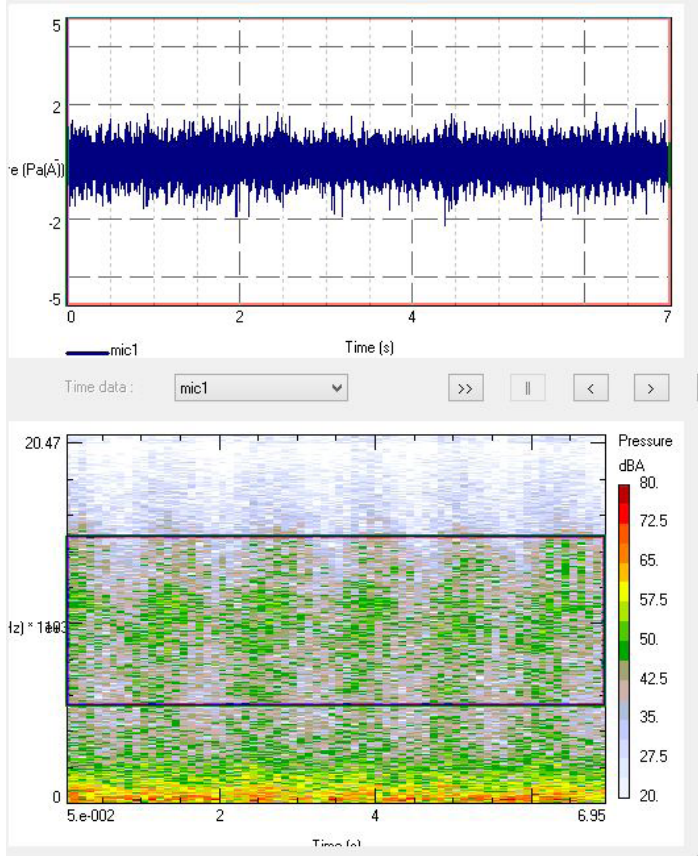
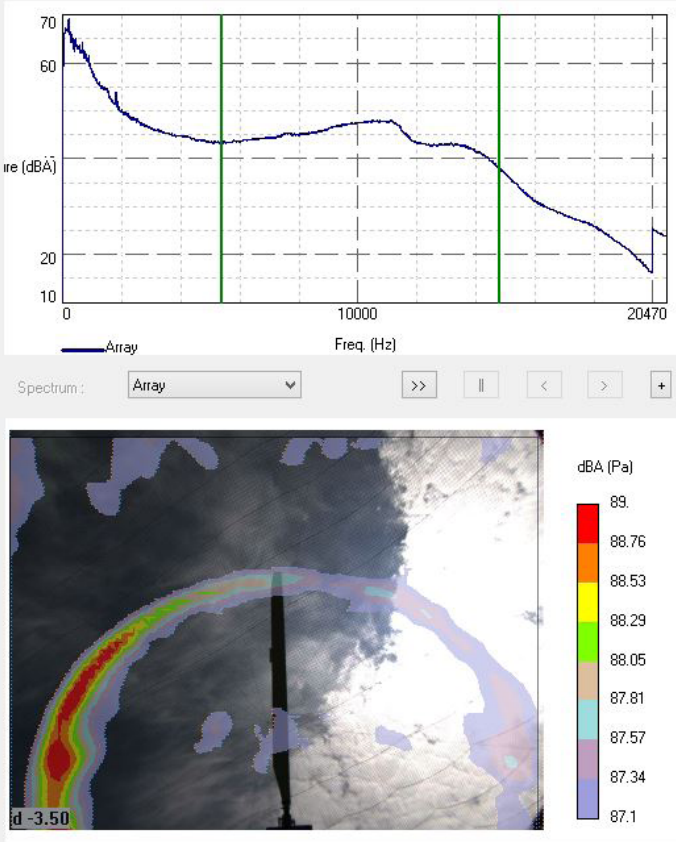

$[0.000 \cdot 7.000 \mathrm{~s}][5440 \cdot 14850 \mathrm{~Hz}]$

Fig. 8. Spectrum and noise sources map - measurement with the acoustic camera under the rotor [S. Cieślak, 2018].

Fig. 9 shows a chart of an acoustic pressure that is measured using a microphone set about $2 \mathrm{~m}$ below the main rotor plane and about $8 \mathrm{~m}$ from the top of blade. The presented pulsations induced pressure increases are due to cyclical movement of shovels and their frequency corresponding to the value of the rotor frequency multiplied by the number of blades (2).

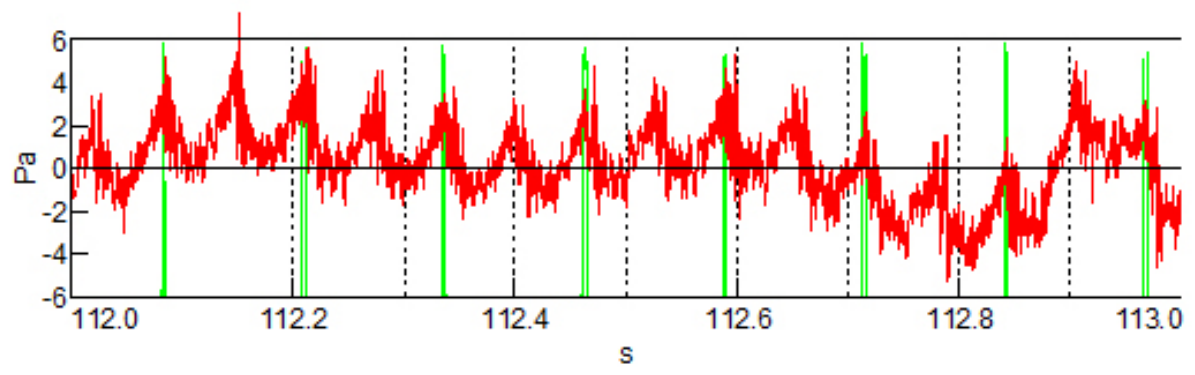

Fig. 9. Pressure pulsation recorded with a microphone under the rotor. [S. Cieślak, 2018].

\section{THE IMPACT FROM THE CHASSIS}

During the tests a typical landing of the helicopter was recorded: landing takes place "on the top of the left runner" by which it is usually mild and therefore does not cause a dynamic (impact) load of helipads (Fig. 10). 


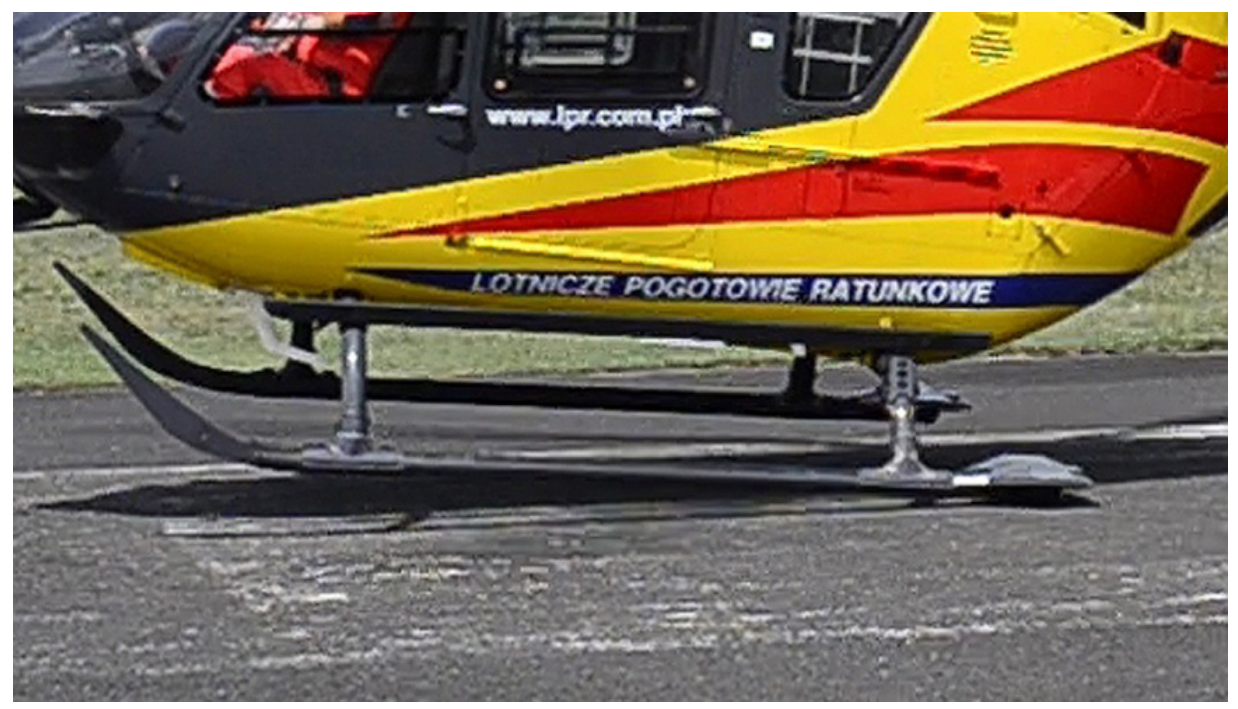

Fig. 10. The moment of landing of helicopter EC-135 [W. Krzymień, 2018].

Information about the landing is useful for an analysis of the cases of hard landing in emergency situations. Point action of the pulse impact, which occurs during landing, during dynamic tests was simulated by modal hammer impact. In such a way without the involvement of the helicopter and its crew, it is possible to carry out vibration plate airfield and building structure induced by the action of the pulse strength.

\section{CONCLUSIONS}

1. The impact of the helicopter on the environment cannot be burdensome, if flights take place not more often than once in a day, however, the participation of helicopters in transporting the sick and injured people will grow.

2. The conditions of the standards and recommendations should be planned in advance, however, the appropriate data to evaluate the impact of the helicopters to hospitals and their surroundings are needed.

3. The main impact of helicopter EC 135 for the environment is engine noise and pressure pulsation from the main rotor. A separate threat to building, patients and staff are the states of emergency such as: a crash with the helipad, blowing from the rotor in case of abnormal landing or take-off, the interference of the flow with the wind (aerodynamic turbulence) or fire.

4. Helicopter EC-135 is relatively quiet and vibration generated by main rotor are controlled and reduced.

\section{BIBLIOGRAFIA}

[1] Law of 8.09.2006 about the State Emergency Medical Services (Dz.U.191 item 1410)

[2] Regulation of the Ministry of Health of 3.11.2011 on Hospital Emergency Ward (Dz.U. 237 item 1420) 
[3] Federal Aviation Administration, US Department of Transportation, 2012, Heliport Design -AC 150/5390-2c, Chapter 4-Hospital Heliports. ,

[4] Wąchalski K., "Assessment of the current construction conditions for elevated helipad on hospital buildings in Poland", Transactions of the Institute of Aviation (244), s. 189-201, Warsaw, 2016.

[5] Cieślak S. and Krzymien W., "Drivetrain noise of the autogiro I-28", Transactions of the Institute of Aviation (250), Warsaw, 2018.

[6] Cieślak S., Krzymień W. Szafran K. "Acoustic characteristics of the cabin of the research platform on the airbag IL-PRC-600M", Transactions of the Institute of Aviation (251), Warsaw, 2018.

[7] Szrajer M. „Badanie symulacyjne rezonansu naziemnego” Prace Instytutu Lotnictwa (119), Warszawa 1989.

[8] Guła P., Gorecki T. "Design, Experiments and Development of a Polish Unmanned Helicopter ILX-27", 39th European Rotorcraft Forum, Moscow, Russia, 3-6 September 2013.

\section{WSTĘPNA ANALIZA ODDZIAEYWANIA NA OTOCZENIE ŚMIGLOWCÓW A LĄDOWISKACH PRZYSZPITALNYCH}

\section{Streszczenie}

Potrzeba szybkiego udzielania pomocy poszkodowanym w wypadkach lub ciężko chorym stworzyło potrzebę budowy lądowisk przy wybranych szpitalach - ich działanie i warunki eksploatacji reguluje Rozporządzenie $M Z$ w sprawie szpitalnego oddziału ratunkowego (SOR) oraz przepisy wymagane przez Urząd Lotnictwa Cywilnego.

Bezpośrednie sąsiedztwo lądowisk powoduje oddziaływanie lądujących i startujących śmigłowców na budynki oraz na ludzi i sprzęt szpitalny a także na konstrukcję lądowiska. W artykule przedstawiono czynniki oddziaływania wibroakustycznego śmigłowców na lądowiskach wyniesionych, metody pomiarowe oraz wyniki wstępnych pomiarów mające na celu oszacowanie wpływu śmigłowców Lotniczego Pogotowia Ratunkowego (LPR) na sąsiadujące budynki i otoczenie.

Słowa kluczowe: lądowiska wyniesione, hałas śmigłowca, badania naziemne. 